В. О. Потапов, Д. А. Хасхачих, Т. В. Демченко, І. С. Гарагуля, В. І. Чуйко ДЗ “Дніпропетровська медична академія МОЗ України”, м. Дніпро

\title{
УПРОВАДЖЕННЯ ІНТЕРНЕТ-СЕРВІСУ SОСRАТІVЕ У НАВЧАЛЬНУ РОБОТУ СТУДЕНТІВ МЕДИЧНИХ ВУЗІВ
}

\author{
V. O. Potapov, D. A. Khaskhachykh, T. V. Demchenko, I. S. Harahulia, V. I. Chuiko \\ SE “Dnipropetrovsk Medical Academy of Health Ministry of Ukraine”, Dnipro \\ THE “SOCRATIVE” INTERNET-SERVICE IMPLEMENTATION TO \\ EDUCATIONAL WORK OF MEDICAL HIGHER EDUCATIONAL \\ INSTITUTIONS' STUDENTS
}

\begin{abstract}
Мета роботи - підвищити якість освіти студентів-медиків через впровадження в навчальний процес інтернет-сервісу Socrative. Основна частина. 3 метою підвищення пізнавального інтересу студентів на кафедрі акушерства та гінекології було впроваджено інтернет-сервіс Socrative, що дозволило проводити повністю електронний поточний та підсумковий тестовий контроль знань. Оскільки на кафедрі є доступним швидкісний інтернет через Wi-Fi, не стало необхідності в утриманні цілого комп’ютерного класу. В якості засобу роботи з тестами стали планшетні комп’ютери кафедри або смартфони студентів 3 доступом до Wi-Fi. Після закінчення тестування студент отримує повідомлення з інформацією про витрачений час та відсоток правильних відповідей, а викладач у режимі реального часу - детальну інформацію про проходження екзамену.

Висновки. Впровадження інформаційно-комунікаційних технологій, зокрема інтернет-сервісу Socrative, у навчальну діяльність кафедри акушерства та гінекології Дніпропетровської медичної академії значно підвищило ергономіку навчальної роботи та ефективність роботи кафедри в цілому, об’єктивність та швидкість взаємодії між викладачами та студентами. Подальше впровадження сучасних комунікаційних технологій дозволить досягти суттєвого економічного ефекту та є майже невичерпним ресурсом подальшого розвитку медичної освіти.
\end{abstract}

Ключові слова: програма Socrative; впровадження; навчальний процес.

The aim of the study - to improve the quality of education through the "Socrative" internet-service implementation to educational work of medical students.

The main body. In order to improve cognitive interests of students at the Department of Obstetrics and Gynecology, the "Socrative" internet-service was implemented, that allowed to conduct fully electronic formative and summative assessment. As far as high-speed internet through Wi-Fi is enabled at the department, there is no longer any necessity in computer lab. Tablet computers of the Department and student's Wi-Fi enabled smartphones have become the tests tools. After test student receives message with information about time spent and correct answers rate and lecturer receives detailed information about examination in online mode.

Conclusion. The implementation of information and communication technologies, including "Socrative" Internet-service, training activities at the Department of Obstetrics and Gynecology of Dnipropetrovsk Medical Academy greatly increased ergonomics and efficiency of educational work of the department as a whole, objectivity and speed of interaction between teachers and students. Further implementation of modern communication technologies will achieve significant economic benefits and is almost inexhaustible resource for the further development of medical education.

Key words: the "Socrative" program; implementation; educational process.

Вступ. Згідно з вимогами законів України “Про пріоритетні напрями розвитку науки і техніки” [1], “Про пріоритетні напрямки інноваційної діяльності в Україні” [2], впровадження в навчальний процес сучасних комп'ютерних технологій сприяє підвищенню ефективності самостійної роботи студентів, сприяє об'єктивній оцінці рівня практичних

(ㄱ В. О. Потапов, Д. А. Хасхачих, Т. В. Демченко та ін. навичок та знань студентів, але навчальні заклади зіштовхуються з проблемою їх використання через брак фінансування і низьким рівнем поширеності комп'ютерної техніки у вищих навчальних закладах. Саме відсутність доступних навчаючих комп'ютерних комплексів суттєво знижує можливості оптимізації самостійної роботи кожного студента, об'єктивної оцінки знань студента та по- 
ліпшення умов праці викладачів [3]. Вирішувати поставлені завдання дозволяє мережа “Інтернет” i поширеність пристроїв до його доступу.

Динамічний розвиток мережі “Інтернет” дозволяє вирішувати нові педагогічні завдання, реалізовувати навчальну діяльність, яка не може бути реалізована поза мережею. Мережа "Інтернет" стає ресурсом і перестає бути тільки каналом, що дозволяє отримати доступ до віддаленого ресурсу. Мережеві сервіси надають право користувачам самостійно створювати контент. Інформацію (текстову, мультимедійну) може розміщувати у всесвітній мережі “Інтернет” будь-який користувач, а інші відвідувачі - використовувати, розвивати, оцінювати та коментувати іiі.

Інтернет $є$ потужним засобом для створення ситуації успіху всіх учасників навчального процесу. На будь-якого типу занятті для студентів медичних вузів (введення нового матеріалу, закріплення, узагальнення, контроль) використання мережевих сервісів мотивує студентів до активної діяльності [4]. Застосування мережевих сервісів дозволяють викладачам підвищити пізнавальний інтерес учнів, добувати інформацію, правильно її обробляти і застосовувати для вирішення поставлених завдань. У даний час існує безліч найрізноманітніших соціальних мережевих сервісів, які викладач може використовувати в освітньому процесі. Робота викладача в освітній системі полягає в організації різноманітної діяльності студентів в освітньому середовищі [5].

Мета роботи - підвищити якість освіти студентівмедиків через впровадження в навчальний процес інтернет-сервісу Socrative.

Використаний інтернет-сервіс Socrative на базі кафедри акушерства та гінекології Дніпропетровської медичної академії для проведення поточного та підсумкового тестового контролю знань студентів. В якості засобу роботи з тестами стали планшетні комп’ютери кафедри або смартфони студентів $з$ доступом до Wi-Fi.

Основна частина. Сервіс Socrative - безкоштовна система збору відповідей студентів через будьякий підключений до Інтернету пристрій (рис. 1). Сервіс Socrative призначений для організації та використання системи тестування з використанням будь-яких гаджетів, комп'ютерів, мобільних пристроїв, на яких можливо працювати з тестами кожного студента в реальному часі. Запустити його можна в якості додатка IOS, Android додатка або на будь-якому браузері. Одночасно можна тестувати до 50 осіб. Даним додатком вже користується більше одного мільйона викладачів і учнів, і їх число зростає з кожним днем [6].

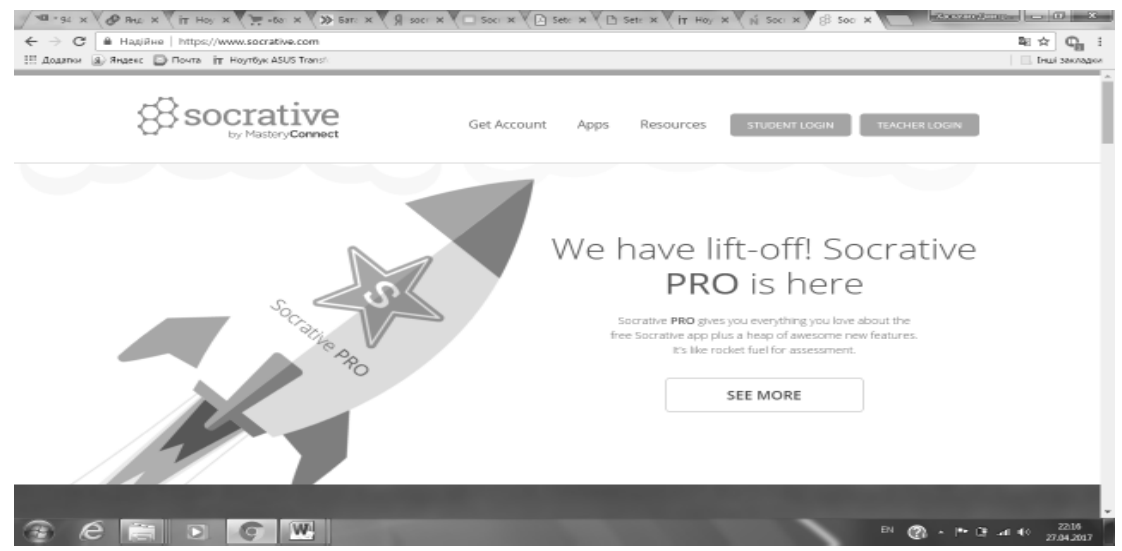

Рис. 1. Головне вікно інтернет-сервісу Socrative.

Тестування або статистичне опитування можливо проводити з будь-якого пристрою, підключеного до Інтернету. Більше того, викладач може легко оцінити прогрес у навчанні студента і всієї групи.

Даний сервіс дозволяє швидко переглянути результати тестування кожного студента в реальному часі (рис. 2), а також зберігає всі результати тестування на сайті програми, які потім можуть бути збережені та роздруковані у форматі Excel або PDF. Сервіс може бути використаний для створення та роботи з опитуваннями, голосуваннями, в дослідженні або проектної діяльності студентів. Сервіс дозволяє використовувати його як в аудиторії, так i при дистанційному навчанні для швидкого опитування і тестування по ходу матеріалу [7]. Socrative можна використовувати для навчання за технологією змішаного навчання “Поза стінами аудиторії”. 


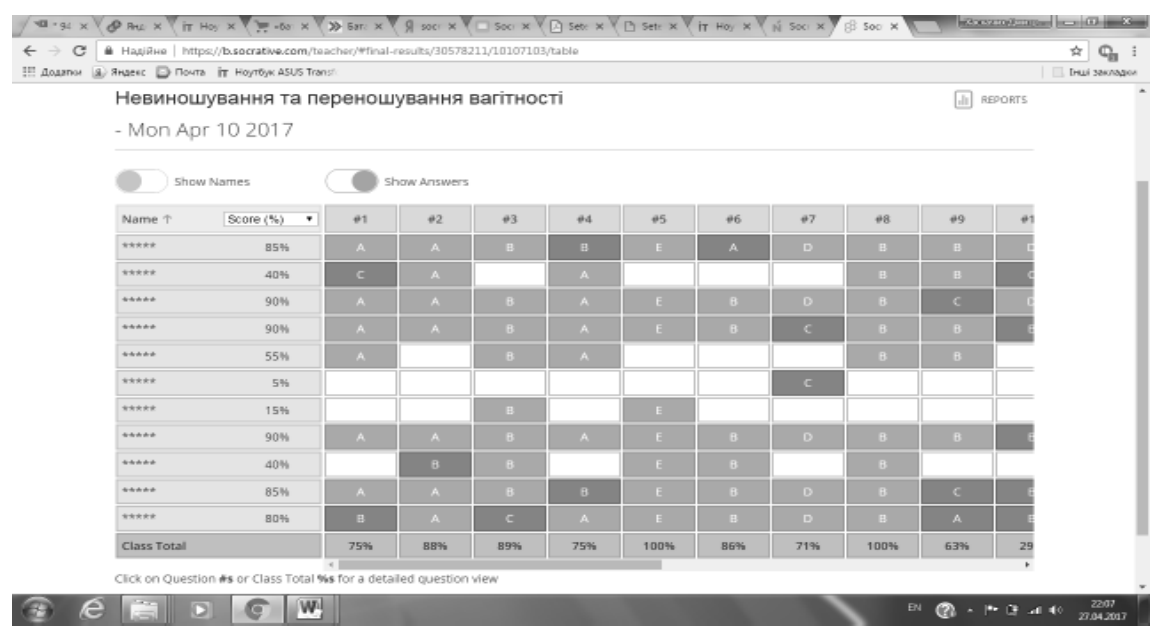

Рис. 2. Відображення результатів тестування інтернет-сервісу Socrative в режимі реального часу.

Переваги використання сервісу Socrative в педагогічній діяльності:

1. Доступність сервісу. Сервіс абсолютно безкоштовний. У цьому його перевага, оскільки не потрібні дорогі системи тестування, наприклад, система голосування SMART Response PE.

2. Охоплення великої кількості студентів (до 50 осіб).

3. Сумісність. Має можливість використання для будь-яких пристроїв (з будь-якими ОС і браузерами).

4. Інтерактивність. Студенти відповідають на питання онлайн, результати тестування видно на екрані викладача миттєво.

5. Корисність. Викладач створює опитування на будь-яку тему, що розширює його можливості.

6. Актуальність. Створюємо опитування на актуальні теми.

Запровадження сервісу Socrative на кафедрі акушерства та гінекології дозволило проведення повністю електронного поточного та підсумкового тестового контролю знань. Оскільки на

\section{Список літератури}

1. Закон України “Про наукову і науково-технічну діяльність”: прийнятий 26 листоп. 2015 року № 848VIII. - Режим доступу : http://zakon4.rada.gov.ua/laws/ show/848-19/page.

2. Закон України "Про пріоритетні напрями інноваційної діяльності в Україні”: прийнятий 08 верес. 2011 року № 3715-VI (із змінами). - Режим доступу : http:// zakon.rada.gov.ua/go/433-15.

3. Запорожан В. М. Інноваційні підходи до підготовки сучасного лікаря / В. М. Запорожан // Медична освіта. 2014. - № 2. - С. 38-40.

4. Натрошвілі С. Г. Інноваційна діяльність вищих навчальних закладів як основа поліпшення якості освітніх кафедрі є доступним швидкісний інтернет через Wi-Fi, не стало необхідності в утриманні цілого комп’ютерного класу. В якості засобу роботи 3 тестами стали планшетні комп’ютери кафедри або смартфони студентів 3 доступом до Wi-Fi. Після закінчення тестування студент отримує повідомлення з інформацією про витрачений час та відсоток правильних відповідей, а викладач у режимі реального часу - детальну інформацію про проходження екзамену.

Висновки. Упровадження інформаційно-комунікаційних технологій у навчальну діяльність кафедри акушерства та гінекології Дніпропетровської медичної академії значно підвищило ергономіку навчальної роботи та ефективність роботи кафедри в цілому, об’ єктивність та швидкість взаємодії між викладачами та студентами. Подальше впровадження сучасних комунікаційних технологій дозволить досягти суттєвого економічного ефекту та $є$ майже невичерпним ресурсом подальшого розвитку медичної освіти.

послуг / С. Г. Натрошвілі // Проблеми науки. - 2012. № 8. - С. 21-26.

5. Козак Л. В. Дослідження інноваційних моделей навчання у вищій школі / Л. В. Козак // Освітологічний дискурс. - 2014. - Т. 1, № 5. - С. 95-107.

6. Web-сервисы для образования. Socrative Teacher. - Peжим доступа : https://sites.google.com/site/badanovweb2/ home/socrative-teacher.

7. Socrative Teacher. Инструкция для начинающих. Презентация. - Режим доступа : https://docs.google.com/ presentation/d/11q6_blwNxLG8A8v4Q0WAtT9qXvOHd3 8cqQKiEpJql8/edit?pli=1. 


\section{References}

1. Zakon Ukrainy Pro naukovu i naukovo-tekhnichnu diialnist: pryiniatyi 26 lys 2015 roku № 848-VIII [Scientific and Technical Activity Act of Ukraine of November 26, 2015, № 848-VIII]. Retrieved from http://zakon4.rada.gov. ua/laws/show/848-19/page [in Ukrainian].

2. Zakon Ukrainy Pro prioritetni napriamy innovatsiinoi diialnosti v Ukraini: pryiniatyi 08 ver 2011. № 3715-VI (iz zminamy) [The Priority Areas of Innovative Activity Act of Ukraine of September 8, 2011, №3715-VI] (as amended). Retrieved from http://zakon.rada.gov.ua/go/433-15 [in Ukrainian].

3. Zaporozhan, V.M. (2014). Innovatsiini pidkhody do pidhotovky suchasnoho likaria [Innovative approaches to modern doctor training]. Medychna osvita - Medical Education, 2, 38-40 [in Ukrainian].

4. Natroshvili, S.H. (2012). Innovatsiina diialnist vyshchykh navchalnykh zakladiv yak osnova polipshennia

Електронна адреса для листування: docdhas@gmail.com yakosti osvitnikh posluh [Innovative activities of higher education institutions as a basis for improving the quality of education]. Problemy nauky - Problems of the Science, 8, 21-26 [in Ukrainian].

5. Kozak, L.V. (2014). Doslidzhennia innovatsiinykh modelei navchannia u vyshchii shkoli [Innovative teaching models at higher education study]. Osvitolohichnyi dyskurs - Educational Discourse, 1 (5), 95-107 [in Ukrainian].

6. Web-servisy dlya obrazovaniya. Socrative Teacher [Web-services for education. Socrative Teacher.] Retrieved from https://sites.google.com/site/badanovweb2/home/ socrative-teacher [in Russian].

7. Socrative Teacher. Instruktsyya dlya nachinayushchikh. Prezentatsyya [Socrative Teacher. Instruction for Beginners. Presentation]. Retrieved from https://docs.google.com/ presentation/d/11q6_blwNxLG8A8v4Q0WAtT9qXvOHd3 8cqQKiEpJql8/edit?pli=1 [in Russian]. 